\title{
Recombinant Human C1 Esterase Inhibitor in the Management of Hereditary Angioedema
}

\author{
Marc Riedl ${ }^{1}$
}

Published online: 20 June 2015

(c) The Author(s) 2015. This article is published with open access at Springerlink.com

\begin{abstract}
Hereditary angioedema (HAE), a rare autosomal dominant genetic disorder, is caused by a deficiency in functional $\mathrm{C} 1$ esterase inhibitor (C1-INH). This potentially life-threatening condition manifests as recurrent attacks of subcutaneous and submucosal swelling of the skin, gastrointestinal tract and larynx. The management of HAE includes treatment of acute episodes, short-term prophylaxis in preparation for exposure to known triggers and long-term prophylaxis to decrease the incidence and severity of HAE attacks. Four products are approved in the USA for the treatment of acute attacks of HAE, including one human plasma-derived C1-INH therapy, a recombinant human C1-INH product (rhC1-INH), a plasma kallikrein inhibitor and a bradykinin B2 receptor antagonist. In addition, one human plasma-derived C1-INH therapy and danazol are approved for prophylaxis of HAE attacks. rhC1-INH, extracted from the milk of transgenic rabbits, is a glycoprotein of 478 amino acids with an identical amino acid sequence to the endogenous human C1-INH protein. Population pharmacokinetic analysis of rhC1-INH supports an intravenous dosing strategy of $50 \mathrm{U} / \mathrm{kg}$ (maximum $4200 \mathrm{U}$ ). The safety and efficacy of rhC1-INH in the treatment of acute attacks in patients with HAE were demonstrated in three randomized, double-blind, placebocontrolled studies and two open-label extension studies. In a pilot prophylaxis study, weekly administration of rhC1INH $50 \mathrm{U} / \mathrm{kg}$ for 8 weeks reduced the incidence of HAE attacks and was well tolerated. Administration of rhC1-
\end{abstract}

Marc Riedl

mriedl@ucsd.edu

1 Division of Rheumatology, Allergy, and Immunology, University of California, San Diego, 8899 University Center Lane, Ste 230, San Diego, CA 92122, USA
INH has not been associated with the development of antidrug antibodies or antibodies to anti-host-related impurities.

\section{Key Points}

Hereditary angioedema (HAE) is a potentially lifethreatening autosomal dominant disorder caused by deficiency of functional $\mathrm{C} 1$ esterase inhibitor (C1INH).

Four products are approved for the treatment of acute HAE in the USA, including one human plasmaderived C1-INH therapy, a recombinant human C1INH product (rhC1-INH), a plasma kallikrein inhibitor and a bradykinin $\mathrm{B} 2$ receptor antagonist. Another human plasma-derived C1-INH therapy and danazol are approved for HAE prophylaxis.

In randomized, controlled trials and open-label extension studies, rhC1-INH has demonstrated efficacy and safety for the treatment of acute attacks of HAE, with preliminary data showing possible utility for long-term HAE prophylaxis.

\section{Introduction}

Hereditary angioedema (HAE) is a rare autosomal dominant genetic disease caused by a quantitative or qualitative deficiency of $\mathrm{C} 1$ esterase inhibitor (C1-INH) [1, 2]. The disease is characterized by recurrent episodes (attacks) of 
subcutaneous and submucosal swelling involving the skin, gastrointestinal tract and larynx [1-3]. Swelling of the larynx can cause fatal asphyxiation [2]. Although the frequency of attacks can vary considerably in untreated patients (every 7-14 days on average), individual HAE attacks generally follow a predictable clinical course of symptoms developing gradually during the first $24 \mathrm{~h}$ and then subsiding during the subsequent $48-72 \mathrm{~h}$ [1]. The prevalence of HAE is unclear; however, it is estimated to affect 1 in 50,000-100,000 individuals globally [4-6]. The onset of symptoms typically begins during childhood; symptoms often worsen during puberty, and HAE attacks generally continue throughout the life of the patient [1]. HAE episodes usually occur without a predictable trigger; however, attacks can be precipitated by minor surgical or dental procedures or trauma, infection and stress [7].

$\mathrm{C} 1-\mathrm{INH}$ is a serine protease inhibitor, which directly or indirectly inhibits several proteases associated with HAE attacks (Fig. 1) [1, 8]. C1-INH is a major inhibitor of several complement proteases such as $\mathrm{C} 1 \mathrm{r}$ and $\mathrm{C} 1 \mathrm{~s}[1,9$, $10]$ and contact proteases, including factor XIIa $[1,11]$ and kallikrein [1, 12], and a minor inhibitor of fibrinolytic proteases such as plasmin and factor XIa [1, 13, 14]. In patients with HAE, uninhibited activation of the contact

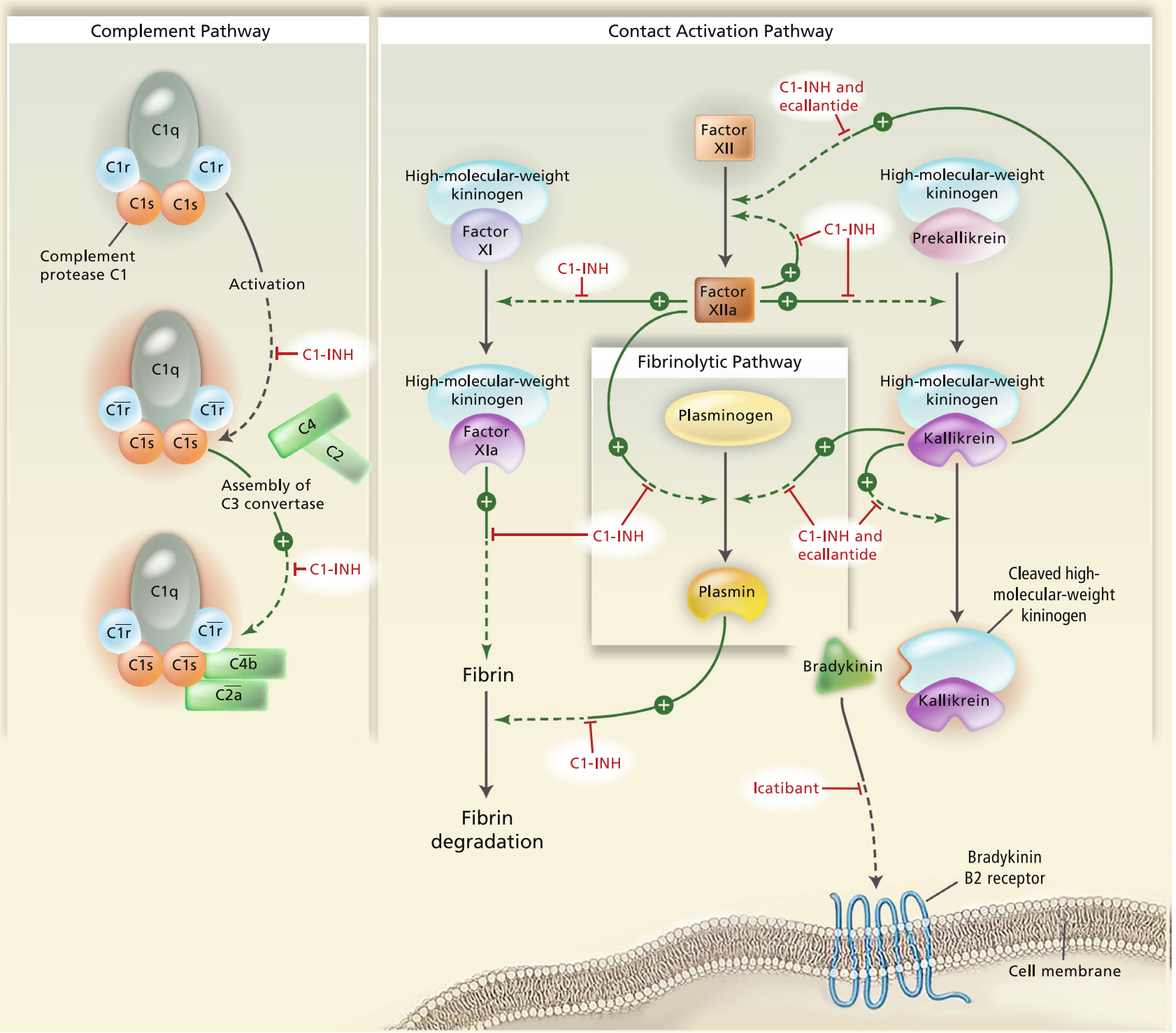

Fig. 1 Schematic representation of the pathways inhibited by $\mathrm{C} 1$ esterase inhibitor (C1-INH). C1-INH inhibits proteases in the complement, contact activation and fibrinolytic pathways. In hereditary angioedema, uninhibited activation of the contact pathway because of deficiency in functional C1-INH results in unregulated cleavage of high molecular weight kininogen by kallikrein, leading to generation of excessive free bradykinin, which is a potent vasoactive peptide. Proteolytic activities are indicated with green arrows, and steps inhibited by C1-INH are shown by red bars. From Zuraw [1]. (C) 2008 Massachusetts Medical Society. Reprinted with permission from Massachusetts Medical Society [1] 
pathway due to insufficient levels of functional C1-INH results in unregulated cleavage of high molecular weight kininogen by kallikrein, leading to generation of excessive free bradykinin [1, 15]. Bradykinin is a potent vasoactive peptide, which mediates increased capillary permeability and oedema $[15,16]$. There are three subtypes of HAE, generally classified according to associated levels and functional activity of C1-INH [1]. Type $\mathrm{I}$ is the most prevalent, accounting for $\sim 85 \%$ of cases, and is defined by a quantitative deficiency of C1-INH protein [1, 17]. Type II HAE ( $\sim 15 \%$ of cases) is associated with normal levels of C1-INH but deficient functional C1-INH activity, as the protein does not function properly. HAE with normal C1-INH (historically referred to as type III) is a rare, largely oestrogen-dependent form of HAE, mostly affecting females; the quantitative and functional levels of $\mathrm{C} 1-\mathrm{INH}$ are normal but patients experience angioedema attacks [1]; the pathophysiology of this HAE subtype is poorly understood.

The management of HAE includes treatment of acute attacks, short-term or procedural prophylaxis (e.g. before dental procedures, minor surgery or endoscopy) and long- term prophylaxis to minimize the frequency and severity of recurrent attacks [4, 18, 19]. Until 2008, management of HAE in the USA was limited to the use of fresh frozen plasma, antifibrinolytic agents, synthetic attenuated androgens and supportive care. Six products are currently approved by the US Food and Drug Administration (FDA) for the acute treatment $(n=4)$ or prophylaxis $(n=2)$ of HAE (Table 1) [20-26]. These products include three C1INH replacement therapies (two human plasma-derived C1-INH preparations [Cinryze ${ }^{\circledR}$ (Shire ViroPharma Inc., Lexington, MA, USA) and Berinert $^{\circledR}$ (CSL Behring $\mathrm{GmbH}$, Marburg, Germany)] and one recombinant human C1-INH preparation [rhC1-INH]), a plasma kallikrein inhibitor (ecallantide), a bradykinin B2 receptor antagonist (icatibant) and a synthetic attenuated androgen (danazol). In Europe, human plasma-derived C1-INH products have been used for more than three decades for the treatment of acute HAE, and icatibant and rhC1-INH have been approved since 2008 and 2010, respectively [27-29]. Although human plasma-derived $\mathrm{C} 1$-INH products have been available globally for many years, there are concerns, as with any plasma-derived product, about the potential

Table 1 US Food and Drug Administration (FDA)-approved agents for the treatment of hereditary angioedema (HAE) [20-26]

\begin{tabular}{|c|c|c|c|c|c|}
\hline $\begin{array}{l}\text { Generic } \\
\text { name }\end{array}$ & Brand name & Description & Mode of administration and dose & Indication & $\begin{array}{l}\text { FDA } \\
\text { approval }\end{array}$ \\
\hline Danazol & $\begin{array}{l}\text { Formerly } \\
\text { marketed as } \\
\text { Danocrine }^{\circledR} \\
\text { in the USA }\end{array}$ & $\begin{array}{l}\text { Synthetic } \\
\text { attenuated } \\
\text { androgen }\end{array}$ & $\begin{array}{l}\text { Oral } \\
\text { Initial dosing 100-200 mg daily. After favorable } \\
\text { initial response (prevention), continuing dose } \\
\text { should be minimized by decreasing dosage as } \\
\text { tolerated based on clinical response and } \\
\text { frequency of attacks }\end{array}$ & $\begin{array}{l}\text { Prevention of angioedema attacks } \\
\text { of all types (cutaneous, } \\
\text { abdominal, laryngeal) in males } \\
\text { and females }\end{array}$ & 1976 \\
\hline $\begin{array}{l}\text { C1 } \\
\text { esterase } \\
\text { inhibitor } \\
\text { (human) }\end{array}$ & Cinryze $\left.^{(}\right)$ & $\begin{array}{l}\text { Plasma- } \\
\text { derived C1 } \\
\text { esterase } \\
\text { inhibitor }\end{array}$ & $\begin{array}{l}\text { IV } \\
1000 \text { U every } 3 \text { or } 4 \text { days } \\
\text { Can be self-administered }\end{array}$ & $\begin{array}{l}\text { Routine prophylaxis against } \\
\text { angioedema attacks in } \\
\text { adolescents and adults with } \\
\text { HAE }\end{array}$ & 2008 \\
\hline $\begin{array}{l}\text { C1 } \\
\text { esterase } \\
\text { inhibitor } \\
\text { (human) }\end{array}$ & Berinert $^{\circledR}$ & $\begin{array}{l}\text { Plasma- } \\
\text { derived C1 } \\
\text { esterase } \\
\text { inhibitor }\end{array}$ & $\begin{array}{l}\text { IV } \\
20 \text { IU per kg body weight } \\
\text { Can be self-administered }\end{array}$ & $\begin{array}{l}\text { Acute abdominal, facial or } \\
\text { laryngeal attacks of HAE in } \\
\text { adolescents (aged } \geq 13 \text { years) } \\
\text { and adults }\end{array}$ & 2009 \\
\hline Ecallantide & Kalbitor $^{\circledR}$ & $\begin{array}{l}\text { Plasma } \\
\text { kallikrein } \\
\text { inhibitor }\end{array}$ & $\begin{array}{l}\mathrm{SC} \\
30 \mathrm{mg}(3 \times 10 \mathrm{mg} \text { injections }) \text {; additional } 30 \mathrm{mg} \\
\text { within } 24 \text {-h period } \\
\text { Should be administered only by a healthcare } \\
\text { provider }\end{array}$ & $\begin{array}{l}\text { Acute } \mathrm{HAE} \text { attacks in patients } \\
\text { aged } \geq 12 \text { years }\end{array}$ & 2009 \\
\hline Icatibant & Firazyr $^{\circledR}$ & $\begin{array}{l}\text { Bradykinin } \\
\text { B2 } \\
\text { receptor } \\
\text { antagonist }\end{array}$ & $\begin{array}{l}\text { SC } \\
30 \text { mg abdominal injection every } 6 \mathrm{~h} \\
\text { (maximum, } 3 \text { doses every } 24 \mathrm{~h} \text { ) } \\
\text { Can be self-administered }\end{array}$ & $\begin{array}{l}\text { Acute } \mathrm{HAE} \text { attacks in adults (aged } \\
\geq 18 \text { years) }\end{array}$ & 2011 \\
\hline $\begin{array}{l}\text { C1 } \\
\text { esterase } \\
\text { inhibitor } \\
\text { (human) }\end{array}$ & Ruconest $^{\circledR}$ & rhC1-INH & $\begin{array}{l}\text { IV } \\
50 \mathrm{IU} / \mathrm{kg}(<84 \mathrm{~kg} \text { body weight }) \text { and } 4200 \mathrm{IU} \\
\quad(\geq 84 \mathrm{~kg} \text { body weight }) ; \leq 2 \text { doses every } 24 \mathrm{~h} \\
\text { Can be self-administered }\end{array}$ & $\begin{array}{l}\text { Acute attacks in adults and } \\
\text { adolescents (investigated in } \\
\text { patients aged } \geq 13 \text { years) with } \\
\text { HAE }\end{array}$ & 2014 \\
\hline
\end{tabular}

$I V$ intravenous, $r h C 1-I N H$ recombinant human $\mathrm{C} 1$ esterase inhibitor, $S C$ subcutaneous 
risk of transmission of blood-borne pathogens, as well as supply issues [27].

This review provides comprehensive information on the synthesis, pharmacokinetics and pharmacodynamics, efficacy and safety of intravenous rhC1-INH for the treatment of patients with HAE. In addition, the product characteristics and safety profile of rhC1-INH are compared with those of human plasma-derived C1-INH products, ecallantide and icatibant. The articles included in this narrative review were identified by a systematic search of PubMed using ("recombinant $\mathrm{cl}$ esterase inhibitor" OR "recombinant C1 inhibitor") AND "hereditary angioedema" keywords for articles in English and consultation of recent review articles for general information on HAE prevalence, aetiology and treatment options. Bibliographies from included articles were reviewed manually for additional relevant studies.

\section{Clinical Pharmacology}

\subsection{Description}

rhC1-INH, a single-chain glycoprotein of 478 amino acids, is derived from milk of transgenic rabbits ( $>99 \%$ purity) using a 3-step Sepharose-based purification procedure including cation exchange chromatography, anion exchange chromatography and affinity chromatography $[30,31]$. The recombinant human formulation was developed as an alternative to human plasma-derived C1-INH to eliminate the risk of transmission of human blood-borne pathogens, as well as to provide a reliable and scalable supply that is not dependent on human plasma donors [8]. It is approved in the European Union and the USA for adults and adolescents (evaluated in individuals $\geq 13$ years of age) for the treatment of acute angioedema attacks in patients with HAE due to C1-INH deficiency [24, 29]. The amino acid sequence of rhC1-INH is identical to that of endogenous human C1-INH but has differences in glycosylation patterns [30].

\subsection{Pharmacokinetics and Pharmacodynamics}

Population pharmacokinetics of rhC1-INH were evaluated by pooling data from six clinical studies in which blood samples were taken before and after intravenous administration of the drug in healthy volunteers, asymptomatic patients with HAE and patients with acute HAE attacks (294 administrations in 133 individuals; dose range 6.25-121 U/kg) [32]. In this analysis, the half-life of rhC1INH was determined to be $\sim 3 \mathrm{~h}$ for a $100 \mathrm{U} / \mathrm{kg}$ dose (similar to the mean half-life of $2.4 \mathrm{~h}$ reported for a $50 \mathrm{U} / \mathrm{kg}$ dose [24]); this interval is shorter than the

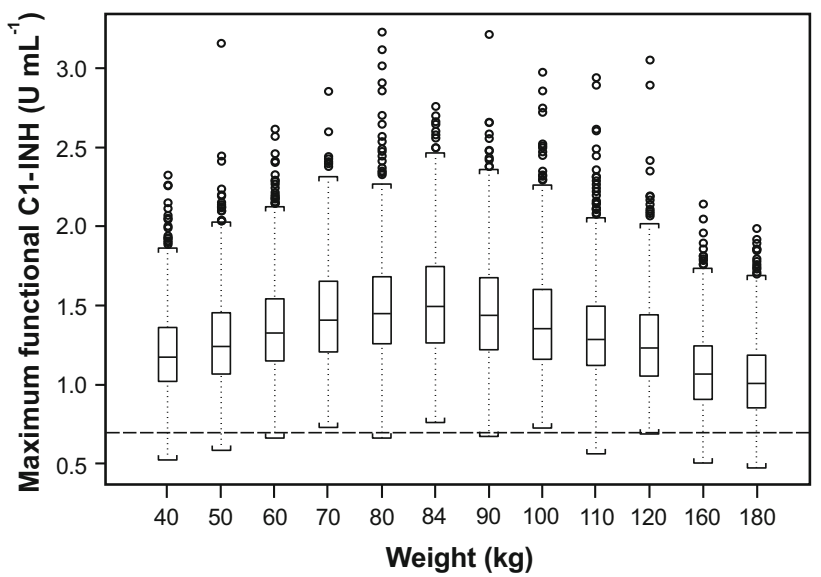

Fig. 2 Simulation of peak recombinant human $\mathrm{C} 1$ esterase inhibitor (rhC1-INH) concentrations for levels of the proposed dosing regimen (50 U/kg for up to $84 \mathrm{~kg}$ body weight and a fixed dose of $4200 \mathrm{U}$ for patients with body weight $>84 \mathrm{~kg}$ ). The 25 th and 75 th percentiles with the median values are represented as boxes; ends of whiskers represent 1.5 times the interquartile ranges (from the 25th and 75 th quartiles). Any observations beyond 1.5 times the interquartile ranges are indicated as open circles, and the dashed line represents the lower limit of normal C1-INH $(0.7 \mathrm{U} / \mathrm{mL})$. Reprinted from Farrell et al. (c) 2013 The British Pharmacological Society [32]

intervals reported for human plasma-derived C1-INH products, which range from 22 to $56 \mathrm{~h}[8,20,21,32-34]$. A higher degree of glycosylation on the rhC1-INH protein results in faster clearance of rhC1-INH from the circulation compared with human plasma-derived C1-INH protein [32].

The pharmacokinetic profile of rhC1-INH was similar after single and multiple dosing [32]. The final estimation of the volume of distribution was $2.9 \mathrm{~L}$, which is consistent with the reported volume of plasma [32, 35]. Based on these analyses, a dosing scheme of $50 \mathrm{U} / \mathrm{kg}$ of rhC1-INH up to $84 \mathrm{~kg}$ body weight and a fixed dose of $4200 \mathrm{U}$ for patients weighing $\geq 84 \mathrm{~kg}$ (Fig. 2) [32] was deemed appropriate to restore functional C1-INH levels. In a separate pharmacokinetic study, 12 asymptomatic patients with HAE receiving $6.25-100 \mathrm{U} / \mathrm{kg}$ of rhC1-INH on two occasions exhibited dose-dependent biological C1-INH activity with increasing plasma complement $\mathrm{C} 4$ levels (twofold after $12 \mathrm{~h}$ of administration of rhC1-INH $100 \mathrm{U} / \mathrm{kg}$ ) and decreasing levels of its cleaved form [31].

\section{Clinical Efficacy}

\subsection{Acute Attacks}

The efficacy of rhC1-INH in the treatment of acute attacks in patients with HAE was evaluated in three randomized, double-blind, placebo-controlled studies and two open-label extension (OLE) studies (Table 2) [36-40]. Two 


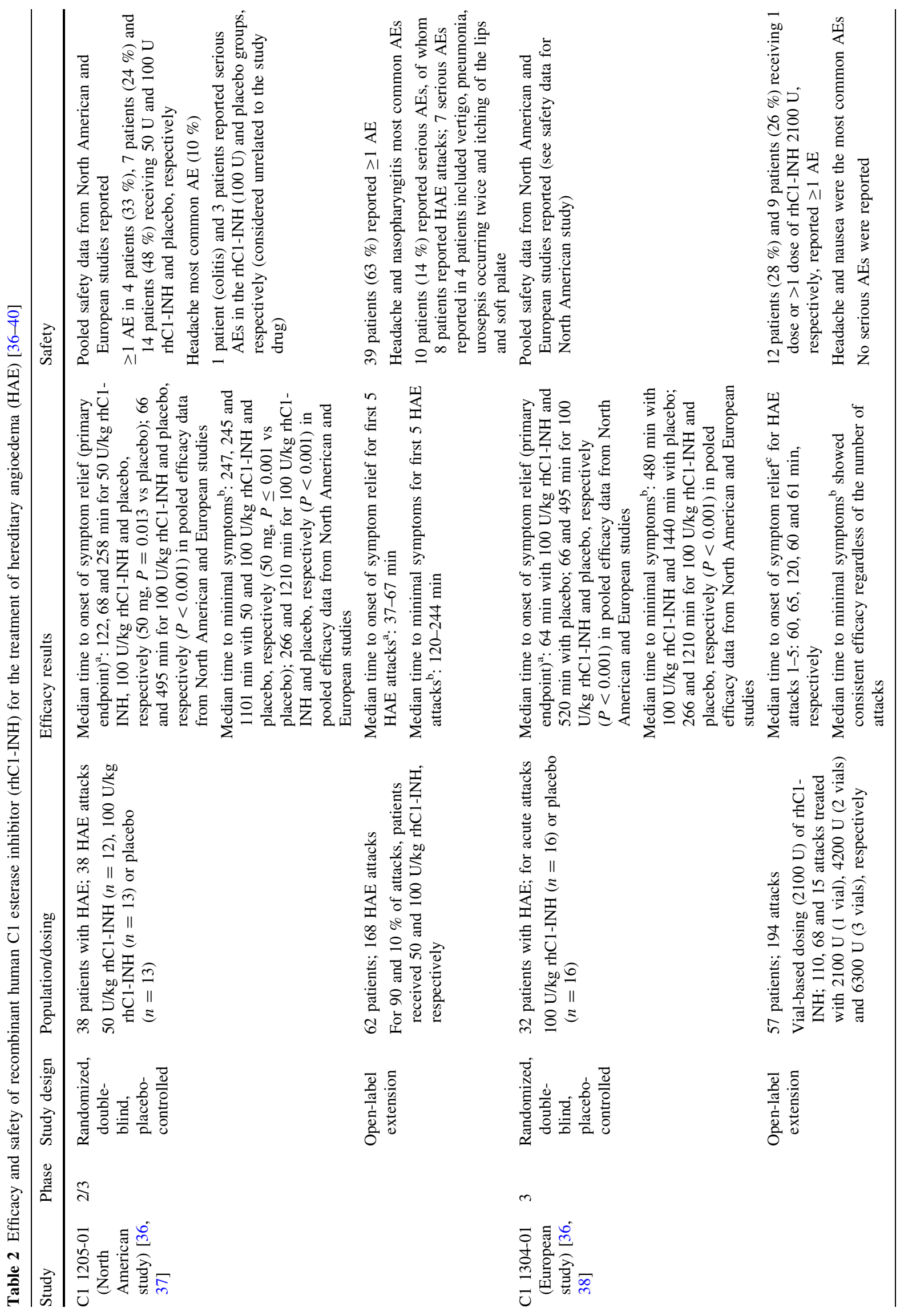




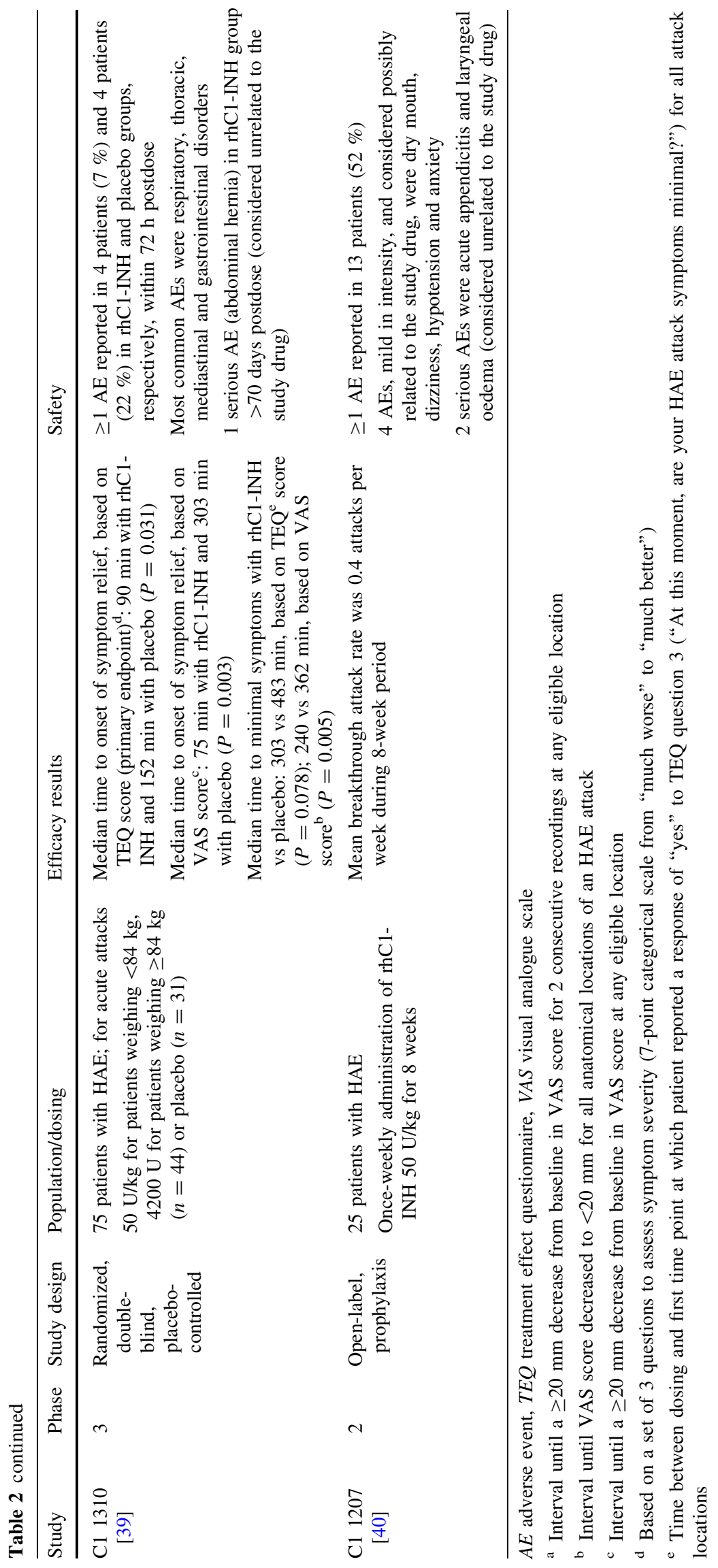


independent, randomized, double-blind, placebo-controlled studies were similarly designed: a North American study (C1 1205-01; $50 \mathrm{U} / \mathrm{kg}[n=12]$ or $100 \mathrm{U} / \mathrm{kg}[n=13]$ rhC1-INH vs placebo $[n=13])$ and a European study (C1 1304-01; $100 \mathrm{U} / \mathrm{kg}$ rhC1-INH $[n=16]$ vs placebo $[n=16]$ ) [36]. Patients included in these trials presented with onset of HAE symptoms within $<5 \mathrm{~h}$ of enrolment and had an overall severity score of $\geq 50 \mathrm{~mm}$ on a visual analogue scale (VAS) [36]. The primary efficacy endpoint was the median time to onset of symptom relief $(\geq 20 \mathrm{~mm}$ decrease from baseline in the VAS score for two consecutive readings) [36]. A pooled analysis of the two studies indicated a significantly faster onset of symptom relief for both doses of rhC1-INH, $50 \mathrm{U} / \mathrm{kg}$ (122 min; $95 \%$ confidence interval [CI] 72-136; $P=0.013)$ and $100 \mathrm{U} / \mathrm{kg}$ (66 min; $95 \%$ CI 61-122; $P<0.001$ ), versus placebo (495 min; $95 \%$ CI 245-520). Although the median time to onset of relief was different for 50 versus $100 \mathrm{U} / \mathrm{kg}$ in the pooled analysis, the $95 \%$ CIs overlapped for these dosing regimens, and Kaplan-Meier plots of both doses showed no significant difference in response. Median time to onset of relief at different anatomical locations (most attacks were peripheral or abdominal) with both doses of rhC1INH (range 50-124 min) was faster than with placebo (range 243-560 min). In addition, treatment with both doses of rhC1-INH significantly reduced the median time to minimal symptoms compared with placebo $(247,266$ and $1210 \mathrm{~min}$ for 50 and $100 \mathrm{U} / \mathrm{kg} \mathrm{rhC} 1-\mathrm{INH}$ and placebo, respectively; $P \leq 0.001$ vs placebo for both rhC1-INH doses) [36].

The efficacy of rhC1-INH observed in the double-blind studies was maintained during treatment of subsequent HAE attacks during the OLE studies [37, 38]. For the first five HAE attacks during the North American OLE study $(n=62)$, the median time to onset of symptom relief ( $>20 \mathrm{~mm}$ decrease from baseline in the VAS score) ranged from 37 to $67 \mathrm{~min}$ and the median time to minimal symptoms (VAS score $<20 \mathrm{~mm}$ ) ranged from 120 to $244 \mathrm{~min}$ [37]. Few attacks $(10.0 \%)$ required treatment with a second dose, and of these, most were oro-facialpharyngeal-laryngeal attacks. Like the North American OLE study, the European OLE study $(n=57)$ supported the continued efficacy of rhC1-INH after repeated treatments for subsequent HAE attacks. The median times to onset of symptom relief ( $\geq 20 \mathrm{~mm}$ decrease from baseline in the VAS score) for HAE attack numbers 1 through 5 were $60,65,120,60$ and $61 \mathrm{~min}$, respectively [38]. By anatomical site, the fastest median time to symptomatic relief occurred with abdominal attacks (33 $\mathrm{min})$, followed by peripheral attacks (61 $\mathrm{min})$, oro-facial-pharyngeal-laryngeal attacks (120 min) and genitourinary attacks (480 min). The faster response observed with abdominal attacks compared with peripheral attacks is theorized to be due to faster resorption of fluid in the submucosal tissue compared with subcutaneous tissue.

In addition, a phase 3, randomized, double-blind, placebo-controlled study was conducted as part of an FDA biologics license application (Study C1 1310) [39]. The study evaluated the efficacy and safety of rhC1-INH (50 U/kg for patients weighing $<84 \mathrm{~kg}$ and $4200 \mathrm{U}$ for patients weighing $\geq 84 \mathrm{~kg}$ ) for the treatment of acute attacks in patients with HAE. The most common primary attack locations (anatomical locations with the highest overall-severity baseline VAS scores) in this study were peripheral (44\%) and abdominal (37\%) [39]. The primary endpoint, median time to onset of symptom relief, was significantly shorter in patients who received rhC1-INH compared with placebo, regardless of the instrument used to assess efficacy: the treatment effect questionnaire (TEQ) score (90 vs 152 min, respectively; $P=0.031$; Fig. 3) [39] or the VAS score (75 vs $303 \mathrm{~min} ; P=0.003$ ). Treatment with rhC1-INH also reduced the median time to minimal

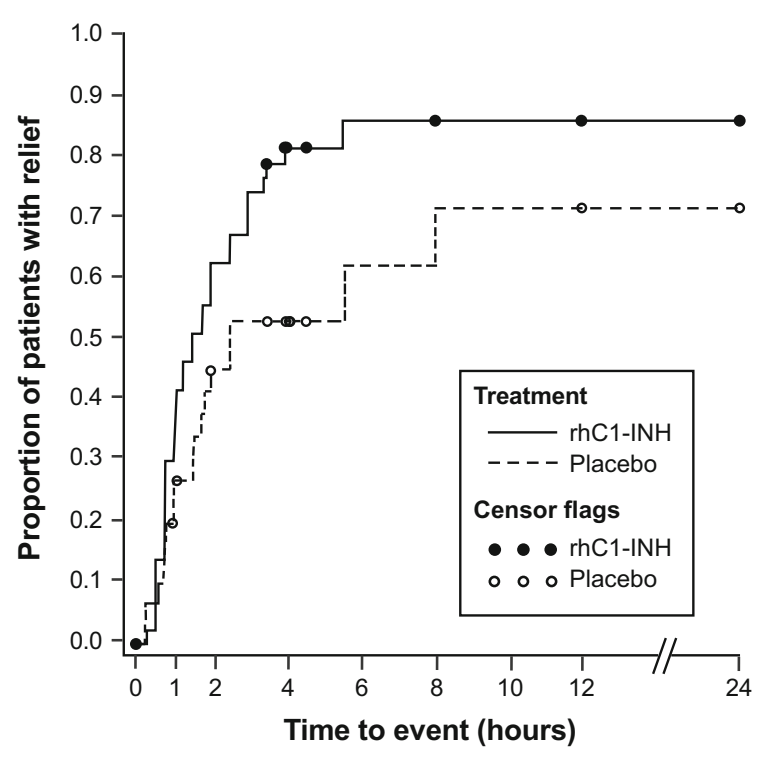

Fig. 3 Kaplan-Meier plot of time to onset of symptom relief based on Treatment Effect Questionnaire results. In this phase 3, randomized, double-blind, placebo-controlled study, patients with an acute attack of hereditary angioedema were treated with recombinant human $\mathrm{C} 1$ esterase inhibitor (rhC1-INH) $(50 \mathrm{U} / \mathrm{kg}$ for patients weighing $<84 \mathrm{~kg}$ and $4200 \mathrm{U}$ for patients weighing $\geq 84 \mathrm{~kg}$ ). The censor flags indicate time points at which data were censored: patients who did not achieve the beginning of persistent symptom relief during the 24-h assessment period were censored at the last assessment time point (i.e. excluded from further efficacy analyses). Patients who received prohibited medications or open-label rescue rhC1-1NH before perceiving persistent symptom relief were censored at the last time point at which the Treatment Effect Questionnaire score was assessed before these medications were administered. Patients who did not experience minimal symptoms during the assessment period also were censored at the last assessment time point. Reprinted from Riedl [39], Copyright 2014, with permission from American College of Allergy, Asthma \& Immunology 
symptoms compared with placebo (303 vs $483 \mathrm{~min}$, respectively [TEQ]; $P=0.078$; or 240 vs $362 \mathrm{~min}$, respectively [VAS]; $P=0.005$ ).

Overall, the efficacy results from three randomized, double-blind, placebo-controlled studies and two OLE studies using a validated VAS instrument showed a consistent benefit of rhC1-INH in the treatment of acute angioedema attacks in patients with HAE [36-39]. Although direct comparisons are not possible because of study design and outcome measure differences, the efficacy data for rhC1-INH in the treatment of acute attacks of HAE appear to be similar to results observed in randomized, placebo-controlled trials of human plasma-derived C1-INH products [41-43]. The median times to onset of patientreported symptom relief were $30 \mathrm{~min}$ with Berinert ${ }^{\circledR}$ $20 \mathrm{U} / \mathrm{kg}$ versus $90 \mathrm{~min}$ with placebo $(P=0.0025)$ [41] and 120 min with Cinryze ${ }^{\circledR} 1000 \mathrm{U}$ versus $>240 \mathrm{~min}$ with placebo $(P=0.02)$ [42].

While not the focus of this review, it should be noted that the kinin pathway modulators ecallantide and icatibant are available as subcutaneous treatment options for acute HAE attacks. Ecallantide, a plasma kallikrein inhibitor, has been evaluated in two randomized, double-blind, placebocontrolled, phase 3 studies [44, 45]. In one study $(n=72)$, ecallantide $30 \mathrm{mg}$ significantly reduced a composite treatment outcome score (range -100 [significant symptom worsening] to +100 [significant symptom improvement]) at $4 \mathrm{~h}$ postdose versus placebo (median score 50.0 vs 0.0 , respectively; $P=0.004$; primary endpoint) [44]. There was no significant difference in the median time to significant improvement (patient-reported outcome of overall symptoms "a lot better or resolved") between ecallantide $(165.0 \mathrm{~min})$ and placebo ( $>240 \mathrm{~min} ; P=0.1)$. In a second study $(n=96)$, a significant improvement from baseline in the mean symptom complex severity score ( $1=$ mild; $2=$ moderate; $3=$ severe $) 4 \mathrm{~h}$ postdose was reported for ecallantide $30 \mathrm{mg}(-0.8 \pm 0.6)$ versus placebo $(-0.4 \pm 0.8 ; P=0.01$; primary endpoint) [45]. Ecallantide is licensed in the USA for the treatment of acute attacks of HAE in patients 12 years and older [46].

Icatibant, a bradykinin $\mathrm{B}_{2}$ receptor antagonist, has been evaluated in three randomized, double-blind, phase 3 trials $[47,48]$. One of the phase 3 studies $(n=56)$ failed to meet the primary endpoint. No significant difference between subcutaneous icatibant $30 \mathrm{mg}$ and placebo in the median time to clinically significant relief $(\geq 30 \%$ decrease from baseline in the VAS score; primary endpoint) of the index symptom was observed (2.5 vs $4.6 \mathrm{~h}$, respectively; $P=0.1)$, while in a second study $(n=74)$ of icatibant $30 \mathrm{mg}$ versus tranexamic acid $3 \mathrm{~g} / \mathrm{day}$, the same primary endpoint was achieved (2.0 vs 12.0, respectively; $P<0.001$ ) [47]. Given the failure to achieve the primary endpoint in the first study, another placebo-controlled study $(n=88)$ was conducted [48]. In this third study, icatibant $30 \mathrm{mg}$ significantly reduced the median time to cutaneous or abdominal attack symptom relief $(50 \%$ reduction from baseline in severity, assessed by a three-symptom [skin swelling, skin pain, abdominal pain] composite VAS score) versus placebo ( 2.0 vs $19.8 \mathrm{~h} ; P<0.001$; primary endpoint). Icatibant is licensed in $\sim 40$ countries, including the USA, for the treatment of acute HAE attacks in patients 18 years and older [23].

\subsection{Prophylaxis}

The efficacy of rhC1-INH (50 U/kg once-weekly administration) for long-term prophylaxis in patients with HAE experiencing frequent attacks ( $\geq 1$ attack every 2 weeks) was evaluated in a pilot open-label study $(n=25)$ for 8 weeks (Table 2) [40]. The mean breakthrough attack rate was 0.4 attacks per week over the 8 -week treatment period. Despite its short half-life, rhC1-INH appeared beneficial for long-term prophylaxis in patients with HAE. However, additional rigorous controlled studies are necessary to determine the true efficacy of rhC1-INH for long-term HAE prophylaxis [25, 42, 49]. Both human plasma-derived C1-INH products have been used for short-term and longterm prophylaxis in HAE as reported in uncontrolled and observational studies $[19,25]$. In addition, in a randomized, double-blind, placebo-controlled, crossover study $(n=22)$ in which Cinryze ${ }^{\circledR} 1000 \mathrm{U}$ or placebo was administered every 3-4 days for 12 weeks, with open-label Cinryze ${ }^{\circledR}$ as rescue treatment for acute attacks, the frequency of HAE attacks was reduced by $\sim 50 \%$ during Cinryze $^{\circledR}$ versus placebo administration [42]. Currently, in the USA, Cinryze $^{\circledR}$ is the only C1-INH agent approved for the routine prophylaxis of HAE attacks. A 12-week, dose-escalation study in 2014 indicated that some patients may require up to $2500 \mathrm{U}$ of Cinryze $^{\circledR}$ every 3-4 days to prevent acute HAE attacks [49].

\section{Safety and Tolerability}

\subsection{Adverse Events}

Safety data from randomized, controlled studies and OLE studies with rhC1-INH (Table 2) support a favourable safety profile [36-40], and results were similar to those reported in clinical trials of human plasma-derived C1-INH products $[41,42]$. Pooled safety data from the two randomized, placebo-controlled studies indicated that 33, 24 and $48 \%$ of patients receiving $50 \mathrm{U} / \mathrm{kg}$ rhC1-INH, $100 \mathrm{U} / \mathrm{kg}$ rhC1-INH and placebo, respectively, had $\geq 1$ adverse event (AE) [36]. Headache was the most common 
$\mathrm{AE}$ in the rhC1-INH $100 \mathrm{U} / \mathrm{kg}$ group (10\%) and the placebo group (14\%); no headaches were reported in the $50 \mathrm{U} / \mathrm{kg}$ group. Headache and vertigo were considered related to rhC1-INH treatment. Colitis was reported in one patient after 31 days of rhC1-INH $100 \mathrm{U} / \mathrm{kg}$ treatment; it was not considered by the investigators to be related to the study drug and was the only serious AE reported in the rhC1-INH groups. In an additional phase 3, randomized, controlled study, 7 and $22 \%$ of patients reported $\geq 1 \mathrm{AE}$ in the rhC1-INH and placebo groups, respectively, within $72 \mathrm{~h}$ of dosing; one serious AE of abdominal hernia in the rhC1-INH group after 70 days of dosing was considered unrelated to the study drug [39].

Safety data reported in the OLE studies were generally similar to those reported in the randomized controlled studies. In the North American OLE study, $63 \%$ of patients reported $\geq 1 \mathrm{AE}$, and most $\mathrm{AEs}$ were mild to moderate in intensity [37]. Twenty serious AEs were reported in ten patients, of which 13 AEs in eight patients were HAE attacks; seven serious AEs reported in four patients included vertigo, pneumonia, urosepsis (two episodes) and itching of the lips and soft palate with no signs of a systemic allergic reaction. In the European OLE study, additional dose(s) of rhC1-INH administered in a subset of patients did not increase the incidence of AEs (28 and $26 \%$ of patients receiving one dose or $\geq 1$ dose of rhC1INH $2100 \mathrm{U}$, respectively), and no serious AEs were reported in this study [38]. In the long-term prophylaxis study with rhC1-INH, $52 \%$ of patients reported $\geq 1 \mathrm{AE}$; two AEs (acute appendicitis and laryngeal oedema) were serious, but neither was considered related to the study drug [40].

An increased risk of thromboembolic complications has been reported with off-label, high-dose use of human plasma-derived C1-INH products, potentially mediated through increased levels of C1-INH, which can interact with fibrinolytic proteases, leading to a risk of thromboembolic adverse effects [20, 21, 50]. However, clinical studies with rhC1-INH have not suggested an increased risk of thromboembolic complications [36-40]. Post hoc analyses of the effects of rhC1-INH on coagulation and fibrinolysis in patients with HAE who participated in the randomized, placebo-controlled North American study further supported that rhC1-INH treatment had no prothrombotic effects in patients with HAE receiving up to $100 \mathrm{U} / \mathrm{kg}[36,51]$.

Regarding the safety and tolerability profile of other acute HAE therapies, the most common AEs reported for ecallantide $(n=255$; pooled data) were headache $(16 \%)$, nausea $(13 \%)$, fatigue $(12 \%)$ and diarrhoea $(11 \%)$ [22]. Anaphylaxis has been reported in $4.0 \%$ of patients treated with ecallantide; thus, a boxed warning in the prescribing information indicates that ecallantide should only be administered by a healthcare provider with appropriate support to manage cases of anaphylaxis, and that patients should be closely monitored due to the similarity between symptoms of hypersensitivity reaction and an HAE attack [22]. Unlike with ecallantide, no events of anaphylaxis have been reported in clinical trials of icatibant [23]. The most commonly reported AEs with icatibant $(n=77$; pooled data) have been injection-site reactions (97\%), pyrexia $(4 \%)$ and increased transaminase levels (4\%) [23].

\subsection{Immunogenicity}

Therapeutic proteins have the risk of eliciting an antibody response to the protein itself (anti-drug antibodies) or to impurities originating from the biological system used to produce the protein (e.g. anti-host-related impurities [antiHRI]) [52]. Because rhC1-INH is derived from the milk of transgenic rabbits and contains a small percentage $(<0.002 \%)$ of HRI, it is contraindicated in patients with known or suspected allergy to rabbits or rabbit-derived products [24]. Data from clinical trials support that rhC1INH has a low potential to induce anti-drug antibodies or anti-HRI responses in patients with HAE [52]. In a pooled analysis of five rhC1-INH clinical studies in symptomatic patients with $\operatorname{HAE}$ ( $n=155 ; 424$ administrations), 1.5 and $1.3 \%$ of all pre-exposure and postexposure tests, respectively, were above the cutoff level (set using plasma samples from $\geq 50$ patients with HAE naïve to rhC1-INH) of the screening assays for anti-C1-INH antibodies. However, these results were not accompanied by any clinical symptoms indicating hypersensitivity or any apparent changes in rhC1-INH efficacy. Anti-HRI antibodies were above the cutoff level in $0.7,1.9$ and $1.6-3.1 \%$ of the screening assay tests before exposure, at 90 days after the first exposure and after repeat rhC1-INH treatment ( 22 or 90 days after repeat exposure), respectively. As with the anti-C1-INH antibody results, positive anti-HRI antibody results were not accompanied by clinical symptoms of hypersensitivity reactions.

The potential of rhC1-INH to induce immunoglobulin E (IgE) antibodies against rabbit milk proteins and other allergens was tested by a retrospective analysis of eight rhC1-INH clinical studies (130 patients with HAE and 14 healthy volunteers; 300 administrations) [53]. Approximately $50 \%$ of individuals were exposed more than once to rhC1INH (median, 2). A total of 24 individuals tested positive for select animal allergens (e.g. rabbit, cow, cat or horse dander) prior to rhC1-INH exposure. Five of these individuals had pre-existing anti-rabbit-epithelium $\operatorname{IgE}$ antibodies, and one of them experienced an anaphylactic reaction, the only such case observed in this study population. This individual received antihistamine and inhaled 
$\beta$-agonist therapy, with normalization of her condition within $1 \mathrm{~h}$. None of these individuals had an increase in anti-rabbit IgE levels after rhC1-INH exposure. Of the 19 of 24 individuals who had pre-exposure positivity for select animal allergens other than rabbit, three $(15.8 \%)$ developed anti-rabbit IgE antibodies after rhC1-INH exposure; none of these individuals experienced allergic-type reactions during treatment with rhC1-INH.

\section{Conclusions}

HAE is a rare genetic disorder caused by a deficiency in functional $\mathrm{C} 1-\mathrm{INH}$, and rapid replacement of functional C1-INH is a treatment strategy for managing HAE attacks. The recombinant technology used for the production of rhC1-INH addresses plasma supply concerns and potential risks for transmissible infections associated with human plasma-derived C1-INH products. Global, multicentre clinical studies have demonstrated that rhC1-INH is efficacious and well tolerated for the treatment of acute HAE attacks. Treatment with rhC1-INH has been shown to produce a rapid and sustained improvement in attack-related clinical symptoms. Preliminary data also suggest that rhC1-INH may be beneficial as long-term prophylaxis in patients with HAE; however, additional controlled studies are needed to validate this finding. A phase 2 prophylaxis study is ongoing, with anticipated completion in 2015. Currently, the clinical management of HAE involves individualized patient treatment plans using licensed medication options to terminate attacks, with additional prophylactic therapy in selected patients. The rapid onset of relief, durable efficacy and favourable safety profile associated with rhC1-INH treatment support its use in acute HAE treatment plans.

Declaration of funding/acknowledgments The author was not provided funding for development of this review. Technical editorial and medical writing assistance was provided by Mary Beth Moncrief, $\mathrm{PhD}$, and Pratibha Hebbar, PhD, of Synchrony Medical Communications, LLC (West Chester, PA, USA). Funding for this support was provided by Salix, a Division of Valeant Pharmaceuticals North America LLC (Bridgewater, NJ, USA).

Disclosures MR reports being a scientific consultant for Biocryst, CSL Behring, Dyax, Isis Pharmaceuticals, Inc., Santarus (previously a wholly owned subsidiary of Salix), Shire and ViroPharma, Inc.; and receiving research funding from Biocryst, CSL Behring, Dyax, Pharming, Shire and ViroPharma.

Open Access This article is distributed under the terms of the Creative Commons Attribution-NonCommercial 4.0 International License (http://creativecommons.org/licenses/by-nc/4.0/), which permits any noncommercial use, distribution, and reproduction in any medium, provided you give appropriate credit to the original author(s) and the source, provide a link to the Creative Commons license, and indicate if changes were made.

\section{References}

1. Zuraw BL. Clinical practice: hereditary angioedema. N Engl $\mathrm{J}$ Med. 2008;359(10):1027-36.

2. Cardarelli W. Managed care implications of hereditary angioedema. Am J Manag Care. 2013;19(7 Suppl):s119-24.

3. Lumry WR, Castaldo AJ, Vernon MK, et al. The humanistic burden of hereditary angioedema: impact on health-related quality of life, productivity, and depression. Allergy Asthma Proc. 2010;31(5):407-14.

4. Craig T, Aygören-Pürsün E, Bork K, et al. WAO guideline for the management of hereditary angioedema. World Allergy Organ J. 2012;5(12):182-99.

5. Bygum A. Hereditary angio-oedema in Denmark: a nationwide survey. Br J Dermatol. 2009;161(5):1153-8.

6. Roche O, Blanch A, Caballero T, et al. Hereditary angioedema due to $\mathrm{C} 1$ inhibitor deficiency: patient registry and approach to the prevalence in Spain. Ann Allergy Asthma Immunol. 2005;94(4):498-503.

7. Gompels MM, Lock RJ, Abinun M, et al. C1 inhibitor deficiency: consensus document. Clin Exp Immunol. 2005;139(3):379-94.

8. Kamaukhova E. C1-esterase inhibitor: biological activities and therapeutic applications. J Hematol Thromb. 2013. doi:10.4172/ jhtd.1000113.

9. Sim RB, Reboul A, Arlaud GJ, et al. Interaction of ${ }^{125}$ I-labelled complement subcomponents $\mathrm{C}-1 \mathrm{r}$ and $\mathrm{C}-1 \mathrm{~s}$ with protease inhibitors in plasma. FEBS Lett. 1979;97(1):111-5.

10. Ziccardi RJ. Activation of the early components of the classical complement pathway under physiologic conditions. J Immunol. 1981;126(5):1769-73.

11. de Agostini A, Lijnen HR, Pixley RA, et al. Inactivation of factor XII active fragment in normal plasma. Predominant role of C-1inhibitor. J Clin Invest. 1984;73(6):1542-9.

12. Schapira M, Scott CF, Colman RW. Contribution of plasma protease inhibitors to the inactivation of kallikrein in plasma. J Clin Invest. 1982;69(2):462-8.

13. Huisman LG, van Griensven JM, Kluft C. On the role of C1inhibitor as inhibitor of tissue-type plasminogen activator in human plasma. Thromb Haemost. 1995;73(3):466-71.

14. Wuillemin WA, Minnema M, Meijers JC, et al. Inactivation of factor XIa in human plasma assessed by measuring factor XIaprotease inhibitor complexes: major role for C1-inhibitor. Blood. 1995;85(6):1517-26.

15. Björkqvist J, Sala-Cunill A, Renne T. Hereditary angioedema: a bradykinin-mediated swelling disorder. Thromb Haemost. 2013;109(3):368-74.

16. Nussberger J, Cugno M, Amstutz C, et al. Plasma bradykinin in angio-oedema. Lancet. 1998;351(9117):1693-7.

17. Rosen FS, Pensky J, Donaldson V, et al. Hereditary angioneurotic edema: two genetic variants. Science. 1965;148(3672):957-8.

18. Zuraw BL, Bernstein JA, Lang DM, et al. A focused parameter update: hereditary angioedema, acquired $\mathrm{C} 1$ inhibitor deficiency, and angiotensin-converting enzyme inhibitor-associated angioedema. J Allergy Clin Immunol. 2013;131(6):1491-3.

19. Cicardi M, Bork K, Caballero T, On behalf of HAWK (Hereditary Angioedema International Working Group), et al. Evidence-based recommendations for the therapeutic management of angioedema owing to hereditary $\mathrm{C} 1$ inhibitor deficiency: consensus report of an international working group. Allergy. 2012;67(2):147-57.

20. Cinryze $^{\circledR}$ (c1 esterase inhibitor [human]) [package insert]. Exton: ViroPharma Biologics, Inc., 2012.

21. Berinert ${ }^{\circledast}[\mathrm{C} 1$ esterase inhibitor (human)] [package insert]. Marburg: CSL Behring GmbH; 2012. 
22. Kalbitor ${ }^{\circledR}$ (ecallantide) injection, for subcutaneous use [package insert]. Burlington: Dyax Corp.; 2012.

23. Firazyr ${ }^{\circledR}$ (icatibant) injection, for subcutaneous use [package insert]. Lexington: Shire Orphan Therapies, Inc.; 2011.

24. Ruconest ${ }^{\circledR}$ (C1 esterase inhibitor [recombinant]) for intravenous use, lyophilized powder for reconstitution [package insert]. Raleigh: Salix Pharmaceuticals, Inc.; 2014.

25. Bork K. Pasteurized and nanofiltered, plasma-derived C1 esterase inhibitor concentrate for the treatment of hereditary angioedema. Immunotherapy. 2014;6(5):533-51.

26. Danocrine ${ }^{\circledR}$ [package insert]. Bridgewater: Sanofi-Aventis US LLC; 2011.

27. Xu YY, Buyantseva LV, Agarwal NS, et al. Update on treatment of hereditary angioedema. Clin Exp Allergy. 2013;43(4):395-405

28. Firazyr ${ }^{\circledR} 30 \mathrm{mg}$ solution for injection in pre-filled syringe [package insert]. Berlin: Shire Orphan Therapies GmbH; 2013.

29. Ruconest ${ }^{\circledR} 2100 \mathrm{U}$ powder for solution for injection [package insert]. Leiden: Pharming Group NV; 2010.

30. van Veen HA, Koiter J, Vogelezang CJ, et al. Characterization of recombinant human $\mathrm{C} 1$ inhibitor secreted in milk of transgenic rabbits. J Biotechnol. 2012;162(2-3):319-26.

31. van Doorn MB, Burggraaf J, van Dam T, et al. A phase I study of recombinant human $\mathrm{C} 1$ inhibitor in asymptomatic patients with hereditary angioedema. J Allergy Clin Immunol. 2005; 116(4):876-83.

32. Farrell C, Hayes S, Relan A, et al. Population pharmacokinetics of recombinant human $\mathrm{C} 1$ inhibitor in patients with hereditary angioedema. Br J Clin Pharmacol. 2013;76(6):897-907.

33. Martinez-Saguer I, Rusicke E, Aygören-Pürsün E, et al. Pharmacokinetic analysis of human plasma-derived pasteurized C1inhibitor concentrate in adults and children with hereditary angioedema: a prospective study. Transfusion. 2010;50(2):354-60.

34. Bernstein JA, Ritchie B, Levy RJ, et al. Population pharmacokinetics of plasma-derived $\mathrm{C} 1$ esterase inhibitor concentrate used to treat acute hereditary angioedema attacks. Ann Allergy Asthma Immunol. 2010;105(2):149-54.

35. Pearson TC, Guthrie DL, Simpson J, et al. Interpretation of measured red cell mass and plasma volume in adults: expert panel on radionuclides of the International Council for Standardization in Haematology. Br J Haematol. 1995;89(4):748-56.

36. Zuraw B, Cicardi M, Levy RJ, et al. Recombinant human C1inhibitor for the treatment of acute angioedema attacks in patients with hereditary angioedema. J Allergy Clin Immunol. 2010;126(4):821-7.

37. Riedl MA, Levy RJ, Suez D, et al. Efficacy and safety of recombinant $\mathrm{C} 1$ inhibitor for the treatment of hereditary angioedema attacks: a North American open-label study. Ann Allergy Asthma Immunol. 2013;110(4):295-9.

38. Moldovan D, Reshef A, Fabiani J, et al. Efficacy and safety of recombinant human $\mathrm{C} 1$-inhibitor for the treatment of attacks of hereditary angioedema: European open-label extension study. Clin Exp Allergy. 2012;42(6):929-35.

39. Riedl MA, Bernstein JA, Li H, et al. Recombinant human C1esterase inhibitor relieves symptoms of hereditary angioedema attacks: phase 3, randomized, placebo-controlled trial. Ann Allergy Asthma Immunol. 2014;112(2):163-9.

40. Reshef A, Moldovan D, Obtulowicz K, et al. Recombinant human $\mathrm{C} 1$ inhibitor for the prophylaxis of hereditary angioedema attacks: a pilot study. Allergy. 2013;68(1):118-24.

41. Craig TJ, Levy RJ, Wasserman RL, et al. Efficacy of human C1 esterase inhibitor concentrate compared with placebo in acute hereditary angioedema attacks. J Allergy Clin Immunol. 2009;124(4):801-8.

42. Zuraw BL, Busse PJ, White M, et al. Nanofiltered C1 inhibitor concentrate for treatment of hereditary angioedema. N Engl J Med. 2010;363(6):513-22.

43. Kawalec P, Holko P, Paszulewicz A, et al. Administration of conestat alfa, human $\mathrm{C} 1$ esterase inhibitor and icatibant in the treatment of acute angioedema attacks in adults with hereditary angioedema due to $\mathrm{C} 1$ esterase inhibitor deficiency. Treatment comparison based on systematic review results. Pneumonol Alergol Pol. 2013;81(2):95-104.

44. Cicardi M, Levy RJ, McNeil DL, et al. Ecallantide for the treatment of acute attacks in hereditary angioedema. N Engl J Med. 2010;363(6):523-31.

45. Levy RJ, Lumry WR, McNeil DL, et al. EDEMA4: a phase 3, double-blind study of subcutaneous ecallantide treatment for acute attacks of hereditary angioedema. Ann Allergy Asthma Immunol. 2010;104(6):523-9.

46. Kalbitor ${ }^{\circledR}$ (ecallantide) injection, for subcutaneous use [package insert]. Burlington: Dyax Corp.; 2014.

47. Cicardi M, Banerji A, Bracho F, et al. Icatibant, a new bradykinin-receptor antagonist, in hereditary angioedema. N Engl J Med. 2010;363(6):532-41.

48. Lumry WR, Li HH, Levy RJ, et al. Randomized placebo-controlled trial of the bradykinin $\mathrm{B}(2)$ receptor antagonist icatibant for the treatment of acute attacks of hereditary angioedema: the FAST-3 trial. Ann Allergy Asthma Immunol. 2011;107(6):529-37.

49. Bernstein JA, Manning ME, $\mathrm{Li} \mathrm{H}$, et al. Escalating doses of $\mathrm{C} 1$ esterase inhibitor (Cinryze) for prophylaxis in patients with hereditary angioedema. J Allergy Clin Immunol Pract. 2014;2(1):77-84.

50. Gandhi PK, Gentry WM, Bottorff MB. Thrombotic events associated with $\mathrm{C} 1$ esterase inhibitor products in patients with hereditary angioedema: investigation from the United States Food and Drug Administration Adverse Event Reporting System database. Pharmacotherapy. 2012;32(10):902-9.

51. Relan A, Bakhtiari K, van Amersfoort ES, et al. Recombinant C1-inhibitor: effects on coagulation and fibrinolysis in patients with hereditary angioedema. BioDrugs. 2012;26(1):43-52.

52. Hack CE, Mannesse M, Baboeram A, et al. Immunogenicity assessment of recombinant human c1-inhibitor: an integrated analysis of clinical studies. BioDrugs. 2012;26(5):303-13.

53. Hack CE, Relan A, Baboeram A, et al. Immunosafety of recombinant human $\mathrm{C} 1$-inhibitor in hereditary angioedema: evaluation of IgE antibodies. Clin Drug Investig. 2013;33(4):275-81. 